$\angle$ Research Square
Preprints are preliminary reports that have not undergone peer review.

They should not be considered conclusive, used to inform clinical practice, or referenced by the media as validated information.

\title{
High-grade ductal carcinoma in-situ detected by microcalcification within borderline phyllodes tumour: A report of a case and literature review
}

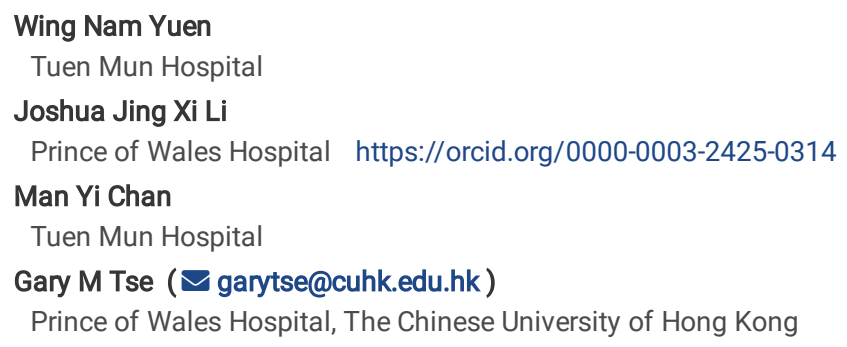




\section{Abstract}

Background

Phyllodes tumour is a rare biphasic neoplasm of the breast that mostly affects middle aged women. Ductal carcinoma in-situ and microcalcifications occurring within phyllodes tumours are documented but are rare findings. Primary surgical excision with adjuvant therapies remains the mainstay of treatment.

Case presentation

We report a case of a 42-year-old woman with high-grade ductal carcinoma in-situ within a borderline phyllodes tumour. Radiologically, clumps of microcalcification were detected within the lesion. Local excision followed by total mastectomy with axillary dissection was then performed. No tumour recurrence was detected up to a period of 8 years.

Conclusion

Presence of microcalcifications within a phyllodes tumour should alert clinicians and pathologists of possible coexisting carcinoma components. Stromal and epithelial components of these lesions should be evaluated separately when formulating a management plan.

\section{Introduction}

Phyllodes tumours (PTs) are rare tumours that constitute less than $1 \%$ of all breast neoplasms. PTs are subclassified into benign, borderline, and malignant based on histologic parameters regarding the stromal component. The parameters are tumour border, stromal cellularity, stromal atypia, mitotic activity, stromal overgrowth, and malignant heterologous elements. Of all PTs, the benign category constitutes $75 \%$, borderline $16 \%$ and malignant $9 \%$ of the cases (1). Epithelial hyperplasia is a common finding that was seen in $74 \%$ of all PTs in one study (1). However, carcinoma within a PT remains rare and accounts for only $1-2 \%$ of all PTs $(2,3)$. Apart from carcinomas within PTs, they can also occur in breast tissues adjacent and ipsilateral to, or contralateral to a PT. In a previous literature review, which discussed PTs associated with carcinomas, carcinoma was more commonly seen within a benign PT whilst in malignant PTs they are more commonly found to be adjacent and ipsilateral to or contralateral to the PTs (4). We hereby report a case of high-grade ductal carcinoma in-situ (DCIS), with microcalcifications detected mammographically, within a PT in a 42-year-old Asian woman.

\section{Case Presentation}

A 42-year-old nulliparous Asian woman was referred for a non-tender right breast mass for one month. She enjoyed good past health and has no known family history of breast cancer. On physical examination, there was a $12 \mathrm{~cm}$ mass occupying the right lateral breast. No skin ulceration was noted. Mammography performed on the right breast showed a dumbbell-shaped mass with well-defined border and clumps of coarse punctate microcalcifications (Fig. 1). Ultrasonography of the index mass showed internal hyperechoic striations and occasional intramural cystic spaces. The overall features were those of BIRADS (Breast Imaging-Reporting and Data System) 4a. The left breast and bilateral axillae showed no significant radiological abnormality. Core biopsy of the index lesion showed findings consistent with fibroadenoma with no definite features of PTs. The patient subsequently underwent local excision of the mass. Gross examination of the excised specimen revealed a $6.5 \times 4.5 \times 4 \mathrm{~cm}$ well-circumscribed tumour showing lobulated growth and white cut surfaces. Necrosis was not observed.

Microscopic examination of the upper lateral tumour showed a well-circumscribed and encapsulated fibroepithelial tumour with pushing border. It consisted of biphasic epithelial and stromal proliferation, forming an extensive leaf-like architecture. The stroma was hypercellular with conspicuous subepithelial accentuation and stromal overgrowth was seen (Fig. 2). No heterologous element was noted. The stromal cells possessed moderate pleomorphism with prominent nucleolus. The mitotic count was 4 per $\mathrm{mm}^{2}$. Adjacent fibroadenomatoid areas were also noted (Fig. 3 ). The DCIS component (measuring $2.7 \mathrm{~cm}$ across) consisted of epithelial cells with cribriform and micropapillary structures with foci of comedonecrosis and abundant luminal calcification (Fig. 4). The epithelial cells possessed enlarged hyperchromatic nuclei with occasional prominent nucleoli. Immunohistochemical study showed diffuse and strong oestrogen receptor staining and loss of CK5/6 staining. A diagnosis of borderline phyllodes tumour with high grade DCIS was therefore made. The resection margin was focally involved by both the phyllodes tumour and DCIS.

The patient subsequently underwent right modified radical mastectomy with axillary dissection of which pathological examination showed no residual tumour or lymph node metastasis. She remained disease free clinically and radiologically at her 8 years follow-up.

\section{Discussion}

To further investigate, a literature research was performed using PubMed database to look for published cases of carcinoma arising within a phyllode tumour. Including this case study, 47 published cases were analysed (Table 1) $(2,4-23,23-41)$. All of them were female patients aged between 19 and 80 years old ( mean age $=47.6$ years old and median age $=49$ years old). The size of the PTs ranged from $1.4 \mathrm{~cm}$ to $21 \mathrm{~cm}($ mean $=7 \mathrm{~cm}$, median $=5.4 \mathrm{~cm})$. The most common carcinoma subtypes reported include DCIS $(n=22)$, followed by mixed in-situ and invasive carcinoma $(n=10)$ and invasive ductal carcinoma (IDC) $(n=7)$. There were 17 malignant PTs, 8 borderline PTs and 22 benign PTs. Invasive carcinomas were found in 7 (41\%) cases of malignant PTs, 5 (63\%) cases of borderline PTs and 8 (36\%) cases of benign PTs. Of note, report of usual ductal hyperplasia within PTs is also most common in borderline PTs (83\%), followed by benign PTs (74\%) and malignant PTs (51\%) (1). 
Table 1

published data of carcinoma arising within a phyllodes tumour.

\begin{tabular}{|c|c|c|c|c|c|c|c|c|c|c|c|}
\hline \multirow[t]{2}{*}{ Case } & \multirow[t]{2}{*}{ First authors } & \multirow[t]{2}{*}{ Year } & \multirow[t]{2}{*}{ Age } & \multicolumn{2}{|c|}{ Phyllodes tumour } & \multicolumn{2}{|c|}{ Carcinoma component } & \multirow{2}{*}{$\begin{array}{l}\text { Presences of } \\
\text { microcalcifications } \\
\text { (characteristics) }\end{array}$} & \multicolumn{3}{|l|}{ Management } \\
\hline & & & & Type & $\begin{array}{l}\text { Size } \\
(\mathrm{cm})\end{array}$ & Type & Size $(\mathbf{c m})$ & & Resection & $\begin{array}{l}\text { Axillary } \\
\text { dissection }\end{array}$ & $\begin{array}{l}\text { Lymph } \\
\text { node } \\
\text { status }\end{array}$ \\
\hline 1 & Leong et al (5) & 1980 & 51 & Benign & 6.0 & LCIS + ITC & $\begin{array}{l}\text { Not } \\
\text { available } \\
\text { (N/A) }\end{array}$ & Yes (not available) & $\begin{array}{l}\text { Mastectomy } \\
(\mathrm{MX})\end{array}$ & Yes & Negativ \\
\hline 2 & $\begin{array}{l}\text { Cole-Beuglet et } \\
\text { al (6) }\end{array}$ & 1983 & 55 & Benign & 1.4 & DCIS + LCIS & N/A & N/A & N/A & No & - \\
\hline 3 & $\begin{array}{l}\text { Cole-Beuglet et } \\
\text { al (6) }\end{array}$ & 1983 & 60 & Benign & 3.0 & IDC & N/A & N/A & N/A & No & - \\
\hline 4 & Grove et al (7) & 1986 & 71 & Benign & 19.0 & DCIS & N/A & No & $\mathrm{MX}$ & Yes & $\begin{array}{l}\text { Negativ } \\
(0 / 11)\end{array}$ \\
\hline 5 & Ishida et al (8) & 1984 & 41 & Benign & 5.6 & IDC & Focal & No & $M X$ & No & N/A \\
\hline 6 & $\begin{array}{l}\text { Kundsen et al } \\
(9)\end{array}$ & 1987 & 71 & Benign & 7.0 & DCIS + LCIS & Multifocal & N/A & $M X$ & Yes & Negativ \\
\hline 7 & $\begin{array}{l}\text { Yasumura et } \\
\text { al (10) }\end{array}$ & 1988 & 47 & Benign & 13.0 & IDC & N/A & N/A & $M X$ & Yes & $\begin{array}{l}\text { Negativ } \\
(0 / 13)\end{array}$ \\
\hline 8 & $\begin{array}{l}\text { Kodama et al } \\
(11)\end{array}$ & 2003 & 47 & Benign & 17.0 & LCIS + ILC & N/A & No & $M X$ & No & - \\
\hline 9 & $\begin{array}{l}\text { Parfitt et al } \\
\text { (12) }\end{array}$ & 2004 & 26 & Benign & 3.3 & DCIS + IDC & Focal & N/A & $\begin{array}{l}\text { Local } \\
\text { excision } \\
\text { (LoEx) }\end{array}$ & Yes & $\begin{array}{l}\text { Positivt } \\
(4 / 13)\end{array}$ \\
\hline 10 & $\begin{array}{l}\text { Ramdass et al } \\
\text { (13) }\end{array}$ & 2006 & 59 & Benign & N/A & $\begin{array}{l}\text { Squamous cell } \\
\text { carcinoma } \\
\text { (SCC) + IDC }\end{array}$ & N/A & N/A & N/A & N/A & N/A \\
\hline 11 & $\begin{array}{l}\text { Yamaguchi et } \\
\text { al (14) }\end{array}$ & 2008 & 54 & Benign & 15.0 & DCIS & Focal & No & $M X$ & No & - \\
\hline 12 & Nio et al (15) & 2011 & 53 & Benign & 3.5 & DCIS & 0.5 & N/A & LoEx & No & - \\
\hline 13 & $\begin{array}{l}\text { Shirah et al } \\
(16)\end{array}$ & 2011 & 49 & Benign & 4.8 & LCIS + ILC & 0.2 (ILC) & N/A & LoEx & No & - \\
\hline 14 & Shin et al (17) & 2013 & 42 & Benign & 1.8 & DCIS & 1.2 & No & LoEx & No & - \\
\hline 15 & $\begin{array}{l}\text { Ghosh et al } \\
\text { (18) }\end{array}$ & 2014 & 42 & Benign & 2.2 & DCIS & N/A & No & LoEx & No & - \\
\hline 16 & $\begin{array}{l}\text { Colakoglu et al } \\
\text { (19) }\end{array}$ & 2014 & 19 & Benign & 1.8 & DCIS & 0.8 & N/A & LoEx & No & - \\
\hline 17 & $\begin{array}{l}\text { Chopra et al } \\
\text { (20) }\end{array}$ & 2016 & 23 & Benign & 5.0 & DCIS & N/A & N/A & LoEx & No & - \\
\hline 18 & Lui et al (21) & 2017 & 19 & Benign & 5.1 & DCIS & N/A & $\begin{array}{l}\text { Yes (specks } \\
\text { described as } \\
\text { benign looking) }\end{array}$ & LoEx & $\begin{array}{l}\text { Sentinel } \\
\text { lymph } \\
\text { node } \\
\text { biopsy } \\
\text { (SLNB) }\end{array}$ & $\begin{array}{l}\text { Negativ } \\
(0 / 2)\end{array}$ \\
\hline 19 & $\begin{array}{l}\text { Panko et al } \\
\text { (22) }\end{array}$ & 2017 & 70 & Benign & 2.3 & DCIS + IDC & 0.5 (IDC) & N/A & LoEx & SLNB & Negativ \\
\hline 20 & Co et al (2) & 2017 & 44 & Benign & 5 & DCIS & Focal & No & $M x$ & No & - \\
\hline 21 & Co et al (2) & 2017 & 25 & Benign & 2.5 & DCIS & Multifocal & No & LoEx & No & - \\
\hline 22 & Sun et al (23) & 2019 & 30 & Benign & 1.5 & DCIS & 0.35 & No & LoEx & No & - \\
\hline 23 & $\begin{array}{l}\text { Deodhar et al } \\
\text { (24) }\end{array}$ & 1997 & 51 & Borderline & 14.0 & DCIS & Focal & N/A & LoEx & N/A & $\mathrm{N} / \mathrm{A}$ \\
\hline 24 & Kuo et al (25) & 2010 & 24 & Borderline & 10.0 & DCIS + IDC & 2.5 & N/A & $M X$ & SLNB & $\begin{array}{l}\text { Isolatec } \\
\text { tumour } \\
\text { cells } \\
(1 / 2)\end{array}$ \\
\hline
\end{tabular}




\begin{tabular}{|c|c|c|c|c|c|c|c|c|c|c|c|}
\hline \multirow[t]{2}{*}{ Case } & \multirow[t]{2}{*}{ First authors } & \multirow[t]{2}{*}{ Year } & \multirow[t]{2}{*}{ Age } & \multicolumn{2}{|c|}{ Phyllodes tumour } & \multicolumn{2}{|c|}{ Carcinoma component } & \multirow{2}{*}{$\begin{array}{l}\text { Presences of } \\
\text { microcalcifications } \\
\text { (characteristics) }\end{array}$} & \multicolumn{3}{|c|}{ Management } \\
\hline & & & & Type & $\begin{array}{l}\text { Size } \\
(\mathrm{cm})\end{array}$ & Type & Size (cm) & & Resection & $\begin{array}{l}\text { Axillary } \\
\text { dissection }\end{array}$ & $\begin{array}{l}\text { Lymph } \\
\text { node } \\
\text { status }\end{array}$ \\
\hline 25 & $\begin{array}{l}\text { Trabelsi et al } \\
\text { (26) }\end{array}$ & 2010 & 52 & Borderline & 15 & DCIS + IDC & Foci & N/A & $\mathrm{MX}$ & No & - \\
\hline 26 & $\begin{array}{l}\text { Quinlan- } \\
\text { Davidson et al } \\
\text { (27) }\end{array}$ & 2011 & 53 & Borderline & 6.5 & LCIS + ITC & 2.4 & Yes (not available) & $M X$ & SLNB & $\begin{array}{l}\text { Negativ } \\
(0 / 3)\end{array}$ \\
\hline 27 & Wu et al (28) & 2014 & 52 & Borderline & 3.0 & IDC & Focal & $\mathrm{N} / \mathrm{A}$ & $\mathrm{MX}$ & Yes & $\begin{array}{l}\text { Positivt } \\
(1 / 21)\end{array}$ \\
\hline 28 & Co et al (2) & 2017 & 54 & Borderline & 9 & DCIS & Focal & No & $M X$ & No & - \\
\hline 29 & $\begin{array}{l}\text { Fischer et al } \\
\text { (29) }\end{array}$ & 2017 & 40 & Borderline & 4.2 & LCIS + ILC & $1.4(\mathrm{ILC})$ & No & $\mathrm{MX}$ & Yes & Negativ \\
\hline 30 & Present study & 2020 & 42 & Borderline & 6.5 & DCIS & $x$ & Yes & $M X$ & Yes & Negativ \\
\hline 31 & $\begin{array}{l}\text { Seemayer et al } \\
(30)\end{array}$ & 1975 & 27 & $\begin{array}{l}\text { Stromal } \\
\text { sarcoma }\end{array}$ & 6.0 & DCIS & Focal & N/A & $\mathrm{MX}$ & No & - \\
\hline 32 & $\begin{array}{l}\text { Klausner et al } \\
(31)\end{array}$ & 1983 & 60 & Malignant & 4.0 & IDC & Focal & N/A & $M X$ & Yes & Negativ \\
\hline 33 & Ward et al (32) & 1986 & 55 & Malignant & 4.0 & LCIS & $\mathrm{N} / \mathrm{A}$ & $\mathrm{N} / \mathrm{A}$ & $M X$ & $\mathrm{~N} / \mathrm{A}$ & N/A \\
\hline 34 & $\begin{array}{l}\text { Padmanabhan } \\
\text { et al (33) }\end{array}$ & 1997 & 47 & Malignant & 7.5 & LCIS & Focal & $\mathrm{N} / \mathrm{A}$ & $\mathrm{MX}$ & Yes & $\begin{array}{l}\text { Negativ } \\
(0 / 4)\end{array}$ \\
\hline 35 & $\begin{array}{l}\text { Nishimura et } \\
\text { al (34) }\end{array}$ & 1997 & 80 & Malignant & 10.5 & DCIS & N/A & N/A & $M X$ & No & - \\
\hline 36 & Lim et al (35) & 2005 & 45 & Malignant & 12.0 & DCIS & 0.6 & N/A & $M X$ & No & - \\
\hline 37 & $\begin{array}{l}\text { Nomura et al } \\
(36)\end{array}$ & 2006 & 75 & Malignant & 3.5 & DCIS & N/A & N/A & $M X$ & Yes & Negativ \\
\hline 38 & $\begin{array}{l}\text { Sugie et al } \\
(37)\end{array}$ & 2007 & 54 & Malignant & 8.0 & SCC & $\mathrm{N} / \mathrm{A}$ & N/A & $M X$ & Yes & Negativ \\
\hline 39 & $\begin{array}{l}\text { Korula et al } \\
\text { (38) }\end{array}$ & 2008 & 51 & Malignant & 21.0 & DCIS & N/A & No & $M X$ & Yes & $\begin{array}{l}\text { Positive } \\
(2 / 12)\end{array}$ \\
\hline 40 & $\begin{array}{l}\text { Macher- } \\
\text { Goeppinger et } \\
\text { al (39) }\end{array}$ & 2010 & 70 & Malignant & 6.0 & IDC & 2.5 & N/A & $M X$ & Yes & Negativ \\
\hline 41 & $\begin{array}{l}\text { Abdul Aziz et } \\
\text { al (4) }\end{array}$ & 2010 & 43 & Malignant & 3.5 & $D C I S+I T C$ & $0.2(\mathrm{ITC})$ & Yes (not available) & LoEx & No & - \\
\hline 42 & Choi et al (40) & 2012 & 62 & Malignant & 10.0 & $\begin{array}{l}\text { Invasive } \\
\text { cribriform } \\
\text { carcinoma }\end{array}$ & 6.0 & N/A & $M X$ & Yes & Negativ \\
\hline 43 & Co et al (2) & 2017 & 52 & Malignant & 10.0 & DCIS & Focal & No & $M X$ & No & - \\
\hline 44 & Co et al (2) & 2017 & 48 & Malignant & 5 & DCIS & Focal & No & $\mathrm{MX}$ & No & - \\
\hline 45 & Co et al (2) & 2017 & 45 & Malignant & 4 & IDC & Focal & Yes (not available) & $\mathrm{Mx}$ & SLNB & Negativ \\
\hline 46 & Sun et al (23) & 2019 & 30 & Malignant & 3.2 & DCIS & 1.5 & $\begin{array}{l}\text { Yes (punctated } \\
\text { clusters, } \\
\text { suspicious } \\
\text { appearing) }\end{array}$ & LoEx & No & - \\
\hline 47 & Kaur et al(41) & 2019 & 26 & Malignant & 9 & $\begin{array}{l}\text { Neuroendocrine } \\
\text { carcinoma }\end{array}$ & $50 \%$ & N/A & LoEx & N/A & N/A \\
\hline
\end{tabular}

The significance of microcalcifications were only discussed in 21 cases, where they were present in both in-situ and invasive carcinomas. Fourteen of them were pure DCIS lesions, in which 5 cases had microcalcifications (33.3\%). The other 7 cases were involved by invasive carcinomas, 4 of which reported microcalcifications (57.1\%) including 2 cases of lobular carcinoma in-situ (LCIS) + invasive tubular carcinoma (ITC), 1 case of DCIS + ITC and a case of IDC; the remaining 3 cases with invasive carcinoma involvement did not have microcalcifications (two cases of LCIS + invasive lobular carcinoma and a case of IDC). Both benign looking specks (21) and suspicious coarse punctuated clusters of microcalcifications (23), such as those seen in this case, had been described in carcinomas.

There were 20 cases with axillary surgery performed. Thirteen cases of which involved invasive carcinoma and 3 of them had lymph node metastasis ( $23 \%$ ); 6 cases were diagnosed with in-situ carcinoma and 1 of them had lymph node metastasis (14\%). All the metastases were of ductal type. This frequency of 
lymph node metastasis is comparable to that of ordinary invasive breast carcinoma not arising from a PT (42). None of the cases had sarcomatous lymph node involvement. The adjuvant modalities used to manage these patients were diverse. Two studies reported disease-related death as a result of distant metastasis of the sarcomatous component $(34,37)$. To date, no study has yet reported distant carcinomatous metastasis. Of the 32 cases with information on outcome and follow-up period available, there was no documented local recurrence (average follow-up period of 34.6 months).

Carcinoma, especially in-situ lesions, within a PT is often not suspected during the initial breast imaging (2). Thus, the carcinoma component is often only diagnosed incidentally on subsequent pathological examination of the core biopsy or excision specimen. The presence of microcalcifications, such as those seen in our case, is unusual for PTs and can alert the treating clinicians for the possibility of a carcinoma component within the PT. A targeted biopsy of the microcalcifications can therefore be performed.

The mainstay of treatment for these lesions is surgical excision followed by adjuvant therapies. The surgical approaches include local excision/lumpectomy (with margin of $1 \mathrm{~cm}$ advocated) $(43-46)$ and mastectomy $(47,48)$. In contrast to true carcinosarcoma, it has been demonstrated that there is lack of clonality between the carcinoma and stromal neoplastic cells in carcinomas within PTs (39). Therefore, both the stromal and epithelial component of these lesions should be evaluated separately when formulating a management plan.

\section{Conclusion}

We have presented a rare case of pure high-grade DCIS, depicted by the presence of microcalcifications seen mammographically, found within a borderline phyllodes tumour. Clinicians and pathologists should be alert about the possibility of a carcinoma component when there are microcalcifications within a lesion with features of PTs. Both the stromal and epithelial components should be taken into account when formulating a management plan. Long-term

follow-up with regular radiological surveillance is also important as prognostic data for this rare lesion is limited. Distant metastasis causing mortality has been reported but only in cases with malignant stromal component.

\section{Abbreviations}

BIRADS - Breast Imaging-Reporting and Data System

CT- Chemotherapy

DCIS - Ductal carcinoma in-situ

HT - Hormonal therapy

IDC - Invasive ductal carcinoma

ITC - Invasive tubular carcinoma

LCIS - Lobular carcinoma in-situ

MX - Mastectomy

N/A - Not available

PT(s) - Phyllodes tumour(s)

RT - Radiotherapy

SCC - Squamous cell carcinoma

SLNB - Sentinel lymph node biopsy

\section{Declarations}

\section{Ethics approval and consent to participate}

Not applicable

\section{Consent for publication}

Written informed consent was obtained from the patient for publication.

Availability of data and material - Data sharing is not applicable to this article as no dataset was generated or analysed in this study.

Competing interest - The authors declare that they have no competing interest.

Funding - No 
Authors' contributions - WNY drafted the manuscript and reviewed the slides and collected clinicopathological data. JJXL edited the manuscript and reviewed the slides. CMY collected and analysed clinical data. GMT conceived the idea of the study, reviewed the slides and critically revised the paper.

Acknowledgements - Not applicable

Authors' information - Optional

\section{References}

1. Tan P-H, Jayabaskar T, Chuah K-L, Lee H-Y, Tan Y, Hilmy M, et al. Phyllodes tumors of the breast: the role of pathologic parameters. Am J Clin Pathol. 2005 Apr;123(4):529-40.

2. Co M, Tse GM, Chen C, Wei J, Kwong A. Coexistence of Ductal Carcinoma Within Mammary Phyllodes Tumor: A Review of 557 Cases From a 20-year Region-wide Database in Hong Kong and Southern China. Clin Breast Cancer. 2018;18(3):e421-5.

3. Norris HJ, Taylor HB. Relationship of histologic features to behavior of cystosarcoma phyllodes. Analysis of ninety-four cases. Cancer. 1967 Dec;20(12):2090-9.

4. Abdul Aziz M, Sullivan F, Kerin MJ, Callagy G. Malignant Phyllodes Tumour with Liposarcomatous Differentiation, Invasive Tubular Carcinoma, and Ductal and Lobular Carcinoma In Situ: Case Report and Review of the Literature. Pathol Res Int. 2010 Jul 5;2010:1-8.

5. Leong AS, Meredith DJ. Tubular carcinoma developing within a recurring cystosarcoma phyllodes of the breast. Cancer. 1980 Oct 15;46(8):1863-7.

6. Cole-Beuglet C, Soriano R, Kurtz AB, Meyer JE, Kopans DB, Goldberg BB. Ultrasound, x-ray mammography, and histopathology of cystosarcoma phylloides. Radiology. 1983 Feb;146(2):481-6.

7. Grove A, Kristensen LD. Intraductal Carcinoma within a Phyllodes Tumor of the Breast: A Case Report. Tumori J. 1986 Apr;72(2):187-90.

8. Ishida T, Izuo M, Kawai T. Breast carcinoma arising in cystosarcoma phyllodes: report of a case with a review of the literature. Jpn J Clin Oncol. 1984 Mar;14(1):99-106.

9. Knudsen PJ, Ostergaard J. Cystosarcoma phylloides with lobular and ductal carcinoma in situ. Arch Pathol Lab Med. 1987 Sep;111(9):873-5.

10. Yasumura T, Matsui S, Hamajima T, Nagashima K, Yamagishi H, Aikawa I, et al. Infiltrating ductal carcinoma developing within cystosarcoma phyllodesa case report. Jpn J Surg. 1988 May;18(3):326-9.

11. Kodama T, Kameyama K, Mukai M, Sugiura H, Ikeda T, Okada Y. Invasive lobular carcinoma arising in phyllodes tumor of the breast. Virchows Arch Int $J$ Pathol. 2003 Jun;442(6):614-6.

12. Parfitt JR, Armstrong C, O'Malley F, Ross J, Tuck AB. In-situ and invasive carcinoma within a phyllodes tumor associated with lymph node metastases. World J Surg Oncol. 2004;2(1):46.

13. Ramdass MJ, Dindyal S. Phyllodes breast tumour showing invasive squamous-cell carcinoma with invasive ductal, clear-cell, secretory, and squamous components. Lancet Oncol. 2006 Oct;7(10):880.

14. Yamaguchi R, Tanaka M, Kishimoto Y, Ohkuma K, Ishida M, Kojiro M. Ductal Carcinoma In Situ Arising in a Benign Phyllodes Tumor: Report of a Case. Surg Today. 2008 Jan;38(1):42-5.

15. Nio Y, Iguchi C, Tsuboi K, Maruyama R. Ductal carcinoma in situ arising within a benign phyllodes tumor: A case report with a review of the literature. Oncol Lett. 2011 Mar;2(2):223-8.

16. Shirah GR, Lau SK, Jayaram L, Bouton ME, Patel PN, Komenaka IK. Invasive lobular carcinoma and lobular carcinoma in situ in a phyllodes tumor. Breast J. 2011 Jun;17(3):307-9.

17. Shin DJ, Kim DB, Roh JH, Kwak BS. Ductal Carcinoma in Situ Arising in a Benign Phyllodes Tumor: A Case Report. J Korean Soc Radiol. $2013 ; 68(5): 423$.

18. Ghosh P, Saha K. Ductal carcinoma in situ in a benign phyllodes tumor of breast: A rare presentation. J Nat Sci Biol Med. 2014 Jul;5(2):470-2.

19. Çolakoğlu MK, Yenidoğan E, Akgül GG, Irkkan S, Özdemir Y, Gülçelik MA, et al. In Situ Ductal Carcinoma Arising in Benign Phyllodes Tumor in 19-Year Old Patient: A Case Report. J Breast Health. 2014 Oct;10(4):239-41.

20. Chopra S, Muralikrishnan V, Brotto M. Youngest case of ductal carcinoma in situ arising within a benign phyllodes tumour: A case report. Int J Surg Case Rep. 2016;24:67-9.

21. Lui S-A, Oh HB, Wang S, Chan CW. Ductal carcinoma in-situ arising within benign phyllodes tumours. Ann R Coll Surg Engl. 2018 Apr;100(4):e97-102.

22. Panko N, Jebran AA, Gomberawalla A, Connolly M. Invasive Ductal Carcinoma within a Benign Phyllodes Tumor. Am J Case Rep. 2017 Jul 20;18:813-6.

23. Sun L, Zhu R, Ginter P, Malik M, Sung K-J, Hughes JM, et al. Coexisting DCIS and phyllodes breast tumors in Young Chinese women: Case series. Int $J$ Surg Case Rep. 2019;56:13-6.

24. Deodhar KK, Baraniya JB, Naresh KN, Shinde SR, Chinoy RF. Cancerization of phyllodes tumour. Histopathology. 1997 Jan;30(1):98-9.

25. Kuo Y-J, Ho DM-T, Tsai Y-F, Hsu C-Y. Invasive Ductal Carcinoma Arising in Phyllodes Tumor with Isolated Tumor Cells in Sentinel Lymph Node. J Chin Med Assoc. 2010 Nov;73(11):602-4.

26. Trabelsi A, Abdelkrim SB, Stita W, Boudagga MZ, Hammedi F, Mokni M. In Situ and Invasive Ductal Carcinoma Within a Borderline Phyllodes Tumor. World J Oncol. 2010 Feb;1(1):42-4.

27. Quinlan-Davidson S, Hodgson N, Elavathil L, Shangguo T. Borderline phyllodes tumor with an incidental invasive tubular carcinoma and lobular carcinoma in situ component: a case report. J Breast Cancer. 2011 Sep;14(3):237-40. 
28. Wu DI, Zhang H, Guo L, Yan XU, Fan Z. Invasive ductal carcinoma within borderline phyllodes tumor with lymph node metastases: A case report and review of the literature. Oncol Lett. 2016 Apr;11(4):2502-6.

29. Fischer KM, Brooks SJ, Ugras J. SK. Invasive lobular carcinoma involving a borderline phyllodes tumor. Breast J. 2018 Nov;24(6):1076-7.

30. Seemayer TA, Tremblay G, Shibata H. The unique association of mammary stromal sarcoma with intraductal carcinoma. Cancer. 1975 Aug;36(2):599605.

31. Klausner JM, Lelcuk S, llia B, Inbar M, Hammer B, Skornik Y, et al. Breast carcinoma originating in cystosarcoma phyllodes. Clin Oncol. 1983 Mar;9(1):714.

32. Ward RM, Evans HL. Cystosarcoma phyllodes. A clinicopathologic study of 26 cases. Cancer. 1986 Nov 15;58(10):2282-9.

33. Padmanabhan V, Dahlstrom JE, Chong GC, Bennett G. Phyllodes tumor with lobular carcinoma in situ and liposarcomatous stroma. Pathology (Phila). 1997 May;29(2):224-6.

34. Nishimura R, Hasebe T, Imoto S, Mukai K. Malignant phyllodes tumour with a noninvasive ductal carcinoma component. Virchows Arch. 1998 Jan 9;432(1):89-93.

35. Lim SM, Tan PH. Ductal carcinoma in situ within phyllodes tumour: a rare occurrence. Pathology (Phila). 2005 Oct;37(5):393-6.

36. Nomura M, Inoue Y, Fujita S, Sakao J, Hirota M, Souda S, et al. A case of noninvasive ductal carcinoma arising in malignant phyllodes tumor. Breast Cancer Tokyo Jpn. 2006;13(1):89-94.

37. Sugie T, Takeuchi E, Kunishima F, Yotsumoto F, Kono Y. A case of ductal carcinoma with squamous differentiation in malignant phyllodes tumor. Breast Cancer Tokyo Jpn. 2007;14(3):327-32.

38. Korula A, Varghese J, Thomas M, Vyas F, Korula A. Malignant phyllodes tumour with intraductal and invasive carcinoma and lymph node metastasis. Singapore Med J. 2008 Nov;49(11):e318-321.

39. Macher-Goeppinger S, Marme F, Goeppert B, Penzel R, Schirmacher P, Sinn HP, et al. Invasive ductal breast cancer within a malignant phyllodes tumor: case report and assessment of clonality. Hum Pathol. 2010 Feb;41(2):293-6.

40. Choi Y, Lee KY, Jang MH, Seol H, Kim S-W, Park SY. Invasive cribriform carcinoma arising in malignant phyllodes tumor of breast: a case report. Korean J Pathol. 2012 Apr;46(2):205-9.

41. Kaur G, Mitra S, Singh G, Bal A. Neuroendocrine carcinoma of the breast arising in malignant phyllodes tumor. Breast J. 2020;26(2):276-7.

42. Carter CL, Allen C, Henson DE. Relation of tumor size, lymph node status, and survival in 24,740 breast cancer cases. Cancer. 1989 Jan;63(1)(1):181-7.

43. Barrio AV, Clark BD, Goldberg JI, Hoque LW, Bernik SF, Flynn LW, et al. Clinicopathologic features and long-term outcomes of 293 phyllodes tumors of the breast. Ann Surg Oncol. 2007 Oct;14(10):2961-70.

44. Ben Hassouna J, Damak T, Gamoudi A, Chargui R, Khomsi F, Mahjoub S, et al. Phyllodes tumors of the breast: a case series of 106 patients. Am J Surg. 2006 Aug;192(2):141-7.

45. Chaney AW, Pollack A, McNeese MD, Zagars GK, Pisters PW, Pollock RE, et al. Primary treatment of cystosarcoma phyllodes of the breast. Cancer. 2000 Oct;1(7):1502-11. 89(.

46. Reinfuss M, Mituś J, Duda K, Stelmach A, Ryś J, Smolak K. The treatment and prognosis of patients with phyllodes tumor of the breast: an analysis of 170 cases. Cancer. 1996 Mar 1;77(5):910-6.

47. Li J, Tsang JY, Chen C, Chan S-K, Cheung S-Y, Wu C, et al. Predicting Outcome in Mammary Phyllodes Tumors: Relevance of Clinicopathological Features. Ann Surg Oncol. 2019 Sep;26(9):2747-58.

48. Co M, Chen C, Tsang JY, Tse G, Kwong A. Mammary phyllodes tumour: a 15-year multicentre clinical review. J Clin Pathol. 2018 Jun;71(6):493-7.

\section{Figures}




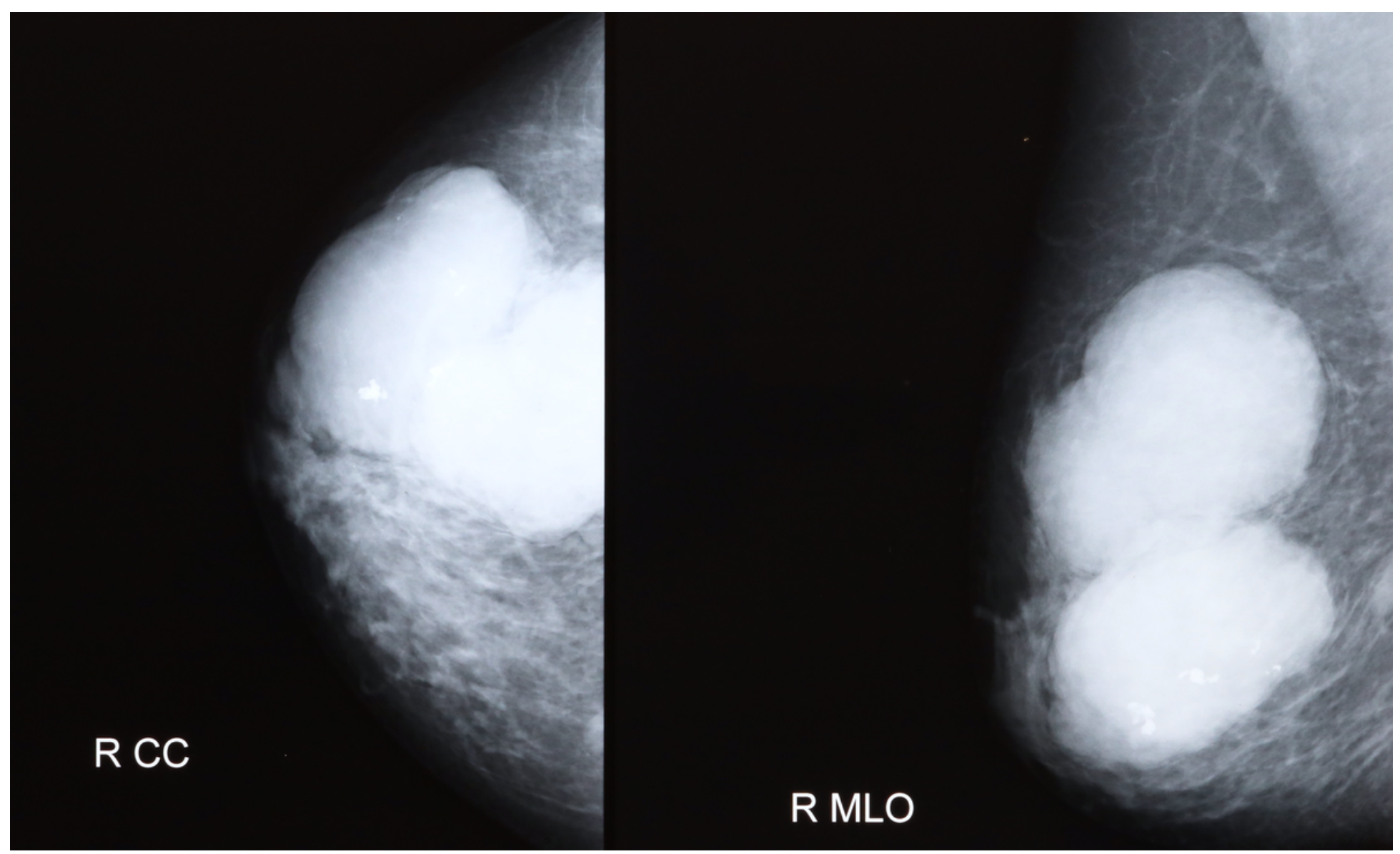

\section{Figure 1}

Mammogram in right craniocaudal (left) and right mediolateral oblique (right) views showing a dumbbell-shaped mass with a well-defined border and clumps of coarse amorphous microcalcifications. 


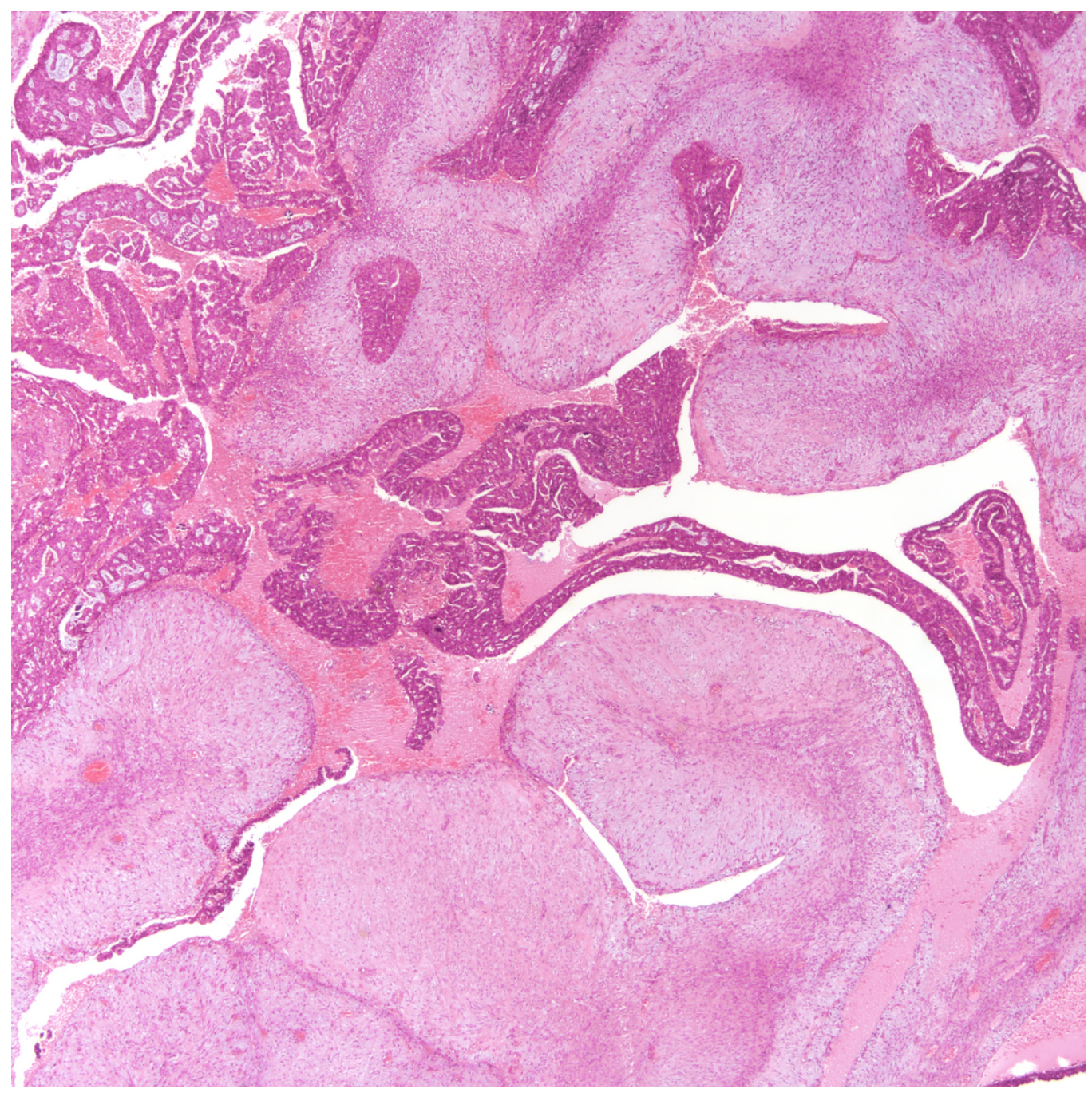

\section{Figure 2}

Borderline phyllodes tumour featuring hypercellular with conspicuous subepithelial accentuation and stromal overgrowth, 20x magnification. 


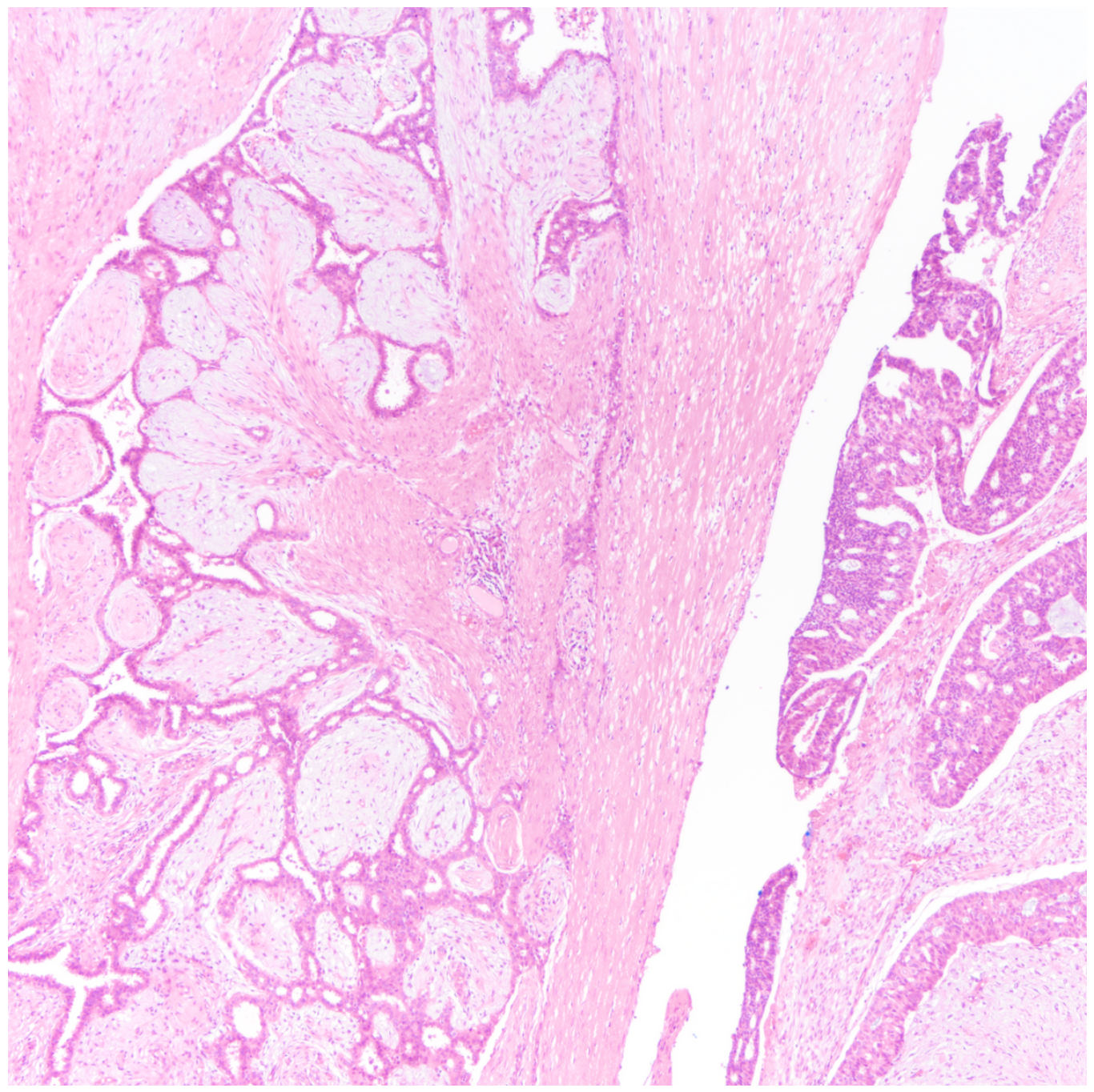

Figure 3

Fibroadenomatoid areas adjacent to borderline phyllodes tumour, 40x magnification. 


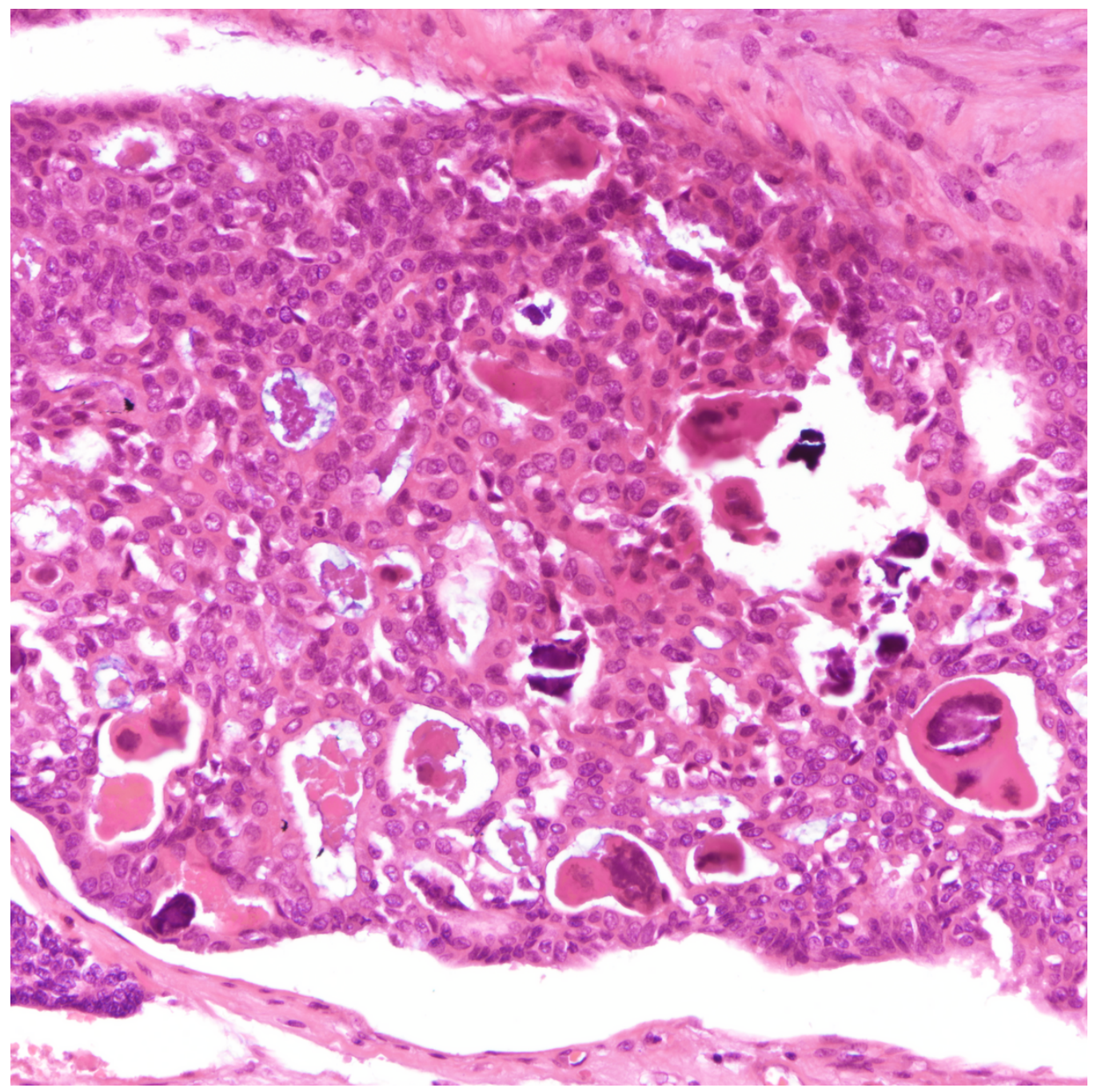

Figure 4

High-grade ductal carcinoma-in-situ with abundant luminal calcification, 200x magnification. 


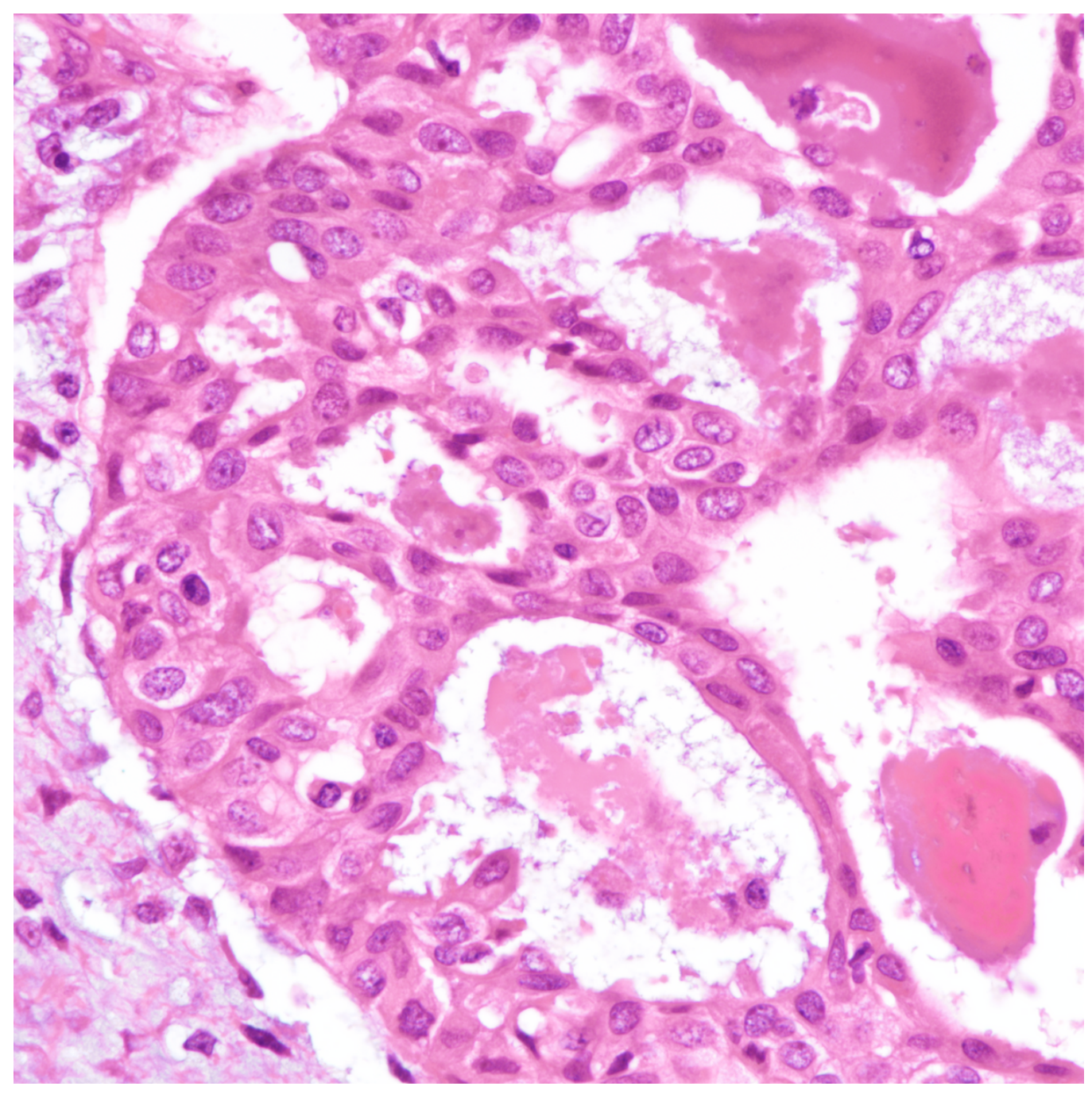

\section{Figure 5}

High-grade cytologic features including nuclear hyperchromasia and prominent nucleoli in high-grade ductal carcinoma-in-situ, 400x magnification.
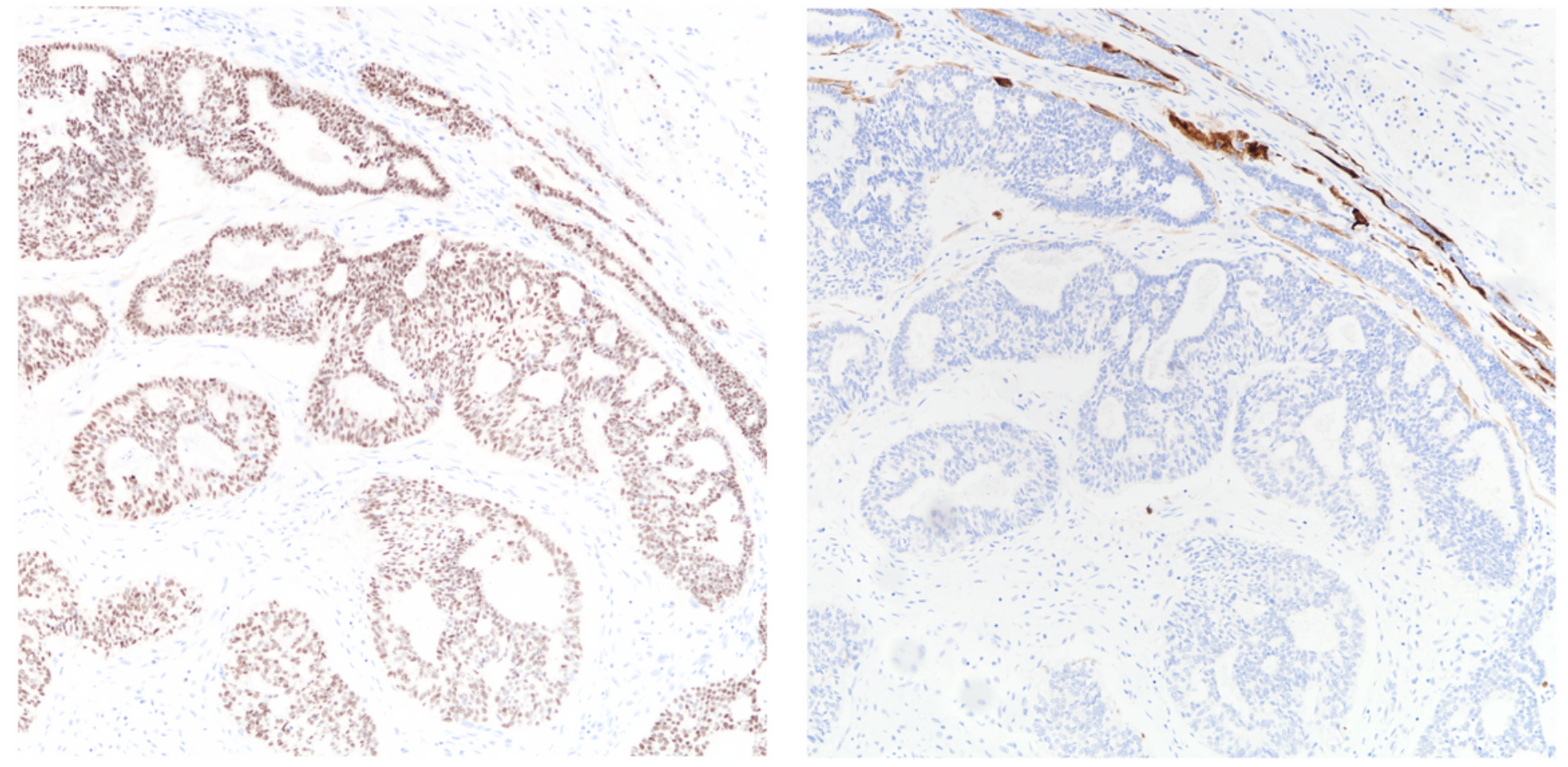
Figure 6

Immunohistochemistry - a) oestrogen receptor, 100x magnification; b) CK5/6, 100x magnification.

\section{Supplementary Files}

This is a list of supplementary files associated with this preprint. Click to download.

- CAREchecklist.pdf 